\title{
Tuz stresinin patateste stoma dayanıklılığı ile ilgili Asg1 geni ifade düzeyine etkileri
}

\section{The effects of salt stress on expression of Asg1 gene related stomatal resistance in potato}

\author{
Serkan URANBEY ${ }^{1}$, Deniz KÖM ${ }^{1}$, Güray AKDOĞAN ${ }^{1}$, Hussein Abdullah Ahmed AHMED ${ }^{2}$, Nilüfer KOÇAK ${ }^{1}$, \\ Muharrem Erdi KARA ${ }^{1}$
}

${ }^{1}$ Ankara Üniversitesi, Ziraat Fakültesi, Tarla Bitkileri Bölümü, 06110 Ankara

${ }^{2}$ Uşak Üniversitesi, Ziraat ve Doğa Bilimleri Fakültesi, Tarla Bitkileri Bölümü, 64200 Uşak

Sorumlu yazar (Corresponding author): S. Uranbey, e-posta (e-mail): uranbey@ankara.edu.tr

\section{MAKALE BİLGİİ}

Alınış tarihi 02 Mayıs 2017

Düzeltilme tarihi 28 Ağustos 2017

Kabul tarihi 13 Eylül 2017

\section{Anahtar Kelimeler:}

Patates

Tuz stresi

In vitro

Asg1 geni

Gen ekspresyonu

\section{Öz}

Abiyotik Stres Geni (Asg1), abssisik asit (ABA) bağımlı yolakta stres koşullarında ozmotik bir pozitif regülatör olup, tuz stresi ile indüklenerek stomal kapanma ve stres koşullarına adaptasyonu teşvik etmekte ve stres sinyal yolağı ile etkileşebilmektedir. Bu çalışmada da, in vitro koşullarda farklı konsantrasyonlarda $(50,100$ ve $150 \mathrm{mM}) \mathrm{NaCl}$ tuz stresine maruz bırakılan Hermes ve Slaney patates çeşitlerinde stoma dayanıklığı ile ilgili Asg1 geninin ifade düzeyleri araştırılmış, tuza toleranslı olduğu düşünülen Slaney çeşidinde $50 \mathrm{mM} \mathrm{NaCl}$ uygulamasında kontrole göre istatistikî anlamda önemli seviyede (\% 90) artış, tuza hassas olduğu düşünülen Hermes çeşidinde ise $50 \mathrm{mM} \mathrm{NaCl}$ uygulamasında kontrole göre \% 16 oranında gen ifadesi düşüşü görülmüştür.

\section{ARTICLE INFO}

Received 02 May 2017

Received in revised form 28 August 2017 Accepted 13 September 2017

\section{Keywords:}

Potato

Salt stress

In vitro

Asg1 gene

Gene expression

\begin{abstract}
Asg1 gene is induced by salt stress and apositive regulator of osmotic stress response related abscisic acid (ABA) dependent pathway. The gene is very effective on stomatal closure and can interact with the salt stress signal pathway. In this study, expression levels of Asg1 gene were investigated in Hermes and Slaney potato varieties subjected to $\mathrm{NaCl}$ salt stress at different concentrations (50,100 and $150 \mathrm{mM}$ ) under in vitro conditions. Asg1 gene showed over expression under salt stress conditions $(50 \mathrm{mM} \mathrm{NaCl})$ in salt tolerant variety Slaney there was a statistically significant $(90 \%)$ increase in the gene expression, however, expression of the gene decreased under salt stress conditions in Hermes variety when compared with control plants.
\end{abstract}

\section{Giriş}

Patates (Solanumtu berosum L.) pek çok kullanım alanı ile günümüzde dünyada yaklaşık şeker kamışı, mısır, çeltik ve buğdayın ardından en çok üretimi yapılan ürünlerin başında gelmektedir. Abiyotik ve biyotik stres faktörleri bitkisel üretimi ciddi ölçüde etkilemekle birlikte, dünyada ve ülkemizde ekolojik olarak geniş bir yelpazede yetiştirilebilen patates tarımında abiyotik ve biyotik stres faktörlerine dayanıklı yeni çeşitlere ihtiyaç vardır . Abiyotik stres faktörlerinin başında gelen tuz stresine bağlı olarak kurak ve yarı kurak bölgelerde ürün verimliliğinin önemli ölçüde azaldığı, dünyadaki karasal alanların \%6'dan fazlasının ve sulanan alanların yaklaşık \% 20'sinin tuzluluktan etkilendiği bilinmektedir (Munns ve Tester 2008). Tuz stresi sonucu oluşan osmotik ve iyon stresi bitki büyümesini olumsuz etkilemekte, tuzluluğun meydana getirdiği bu stres faktörüne karşı çeşitli biyokimyasal ve moleküler mekanizmalar devreye girmektedir. Ozmolit sentezi, iyon kanalları, sinyal faktörleri ve tuza cevap ve detoksifikasyon enzimlerine ait proteinleri kodlayan genler, transkripsiyon faktörleri ve sinyal yolaklarından yer alan genler görev almakta, çok sayıda gen ifadesinin stres koşullarında artığı bilinmektedir (Zhu 2002; Kreps ve ark. 2002; Seki ve ark. 2003; Sahi ve ark. 2006; Tuteja 2007; Çulha ve Çakırlar 2011). Patates bitkisi de tuzluluğa hassas olan türlerden bir olup (Maas 1984), patateste de tuz stresi altında çok sayıda farklı metobolik işlemde rol oynayan gen ve transkripsiyon faktörleri rol oynamaktadır (Shimazaki ve ark. 2016). Bu genlerden biri olan 
abiyotik stres geni (Asg1) bitki hücrelerinde, biyolojik fonksiyonu öngörülebilen dizilerle benzerlikleri göstermese de, işlevsel analizi sonucu patates ve Arobidobsis bitkisinde stres tepki mekanizmasına katkıda bulunabileceği ve bu genin stomal kapanma stres koşullarına adaptasyonu teşvik ederek, stoma dayanıklılığını artırdığı buna bağlı olarak, stres sinyal yolağı ile etkileşebileceği ortaya konmuştur (Batelli ve ark. 2012). Bu çalışmada da, daha önceki in vitro çalışmalarda tuza toleransı bakımından hassas ve dayanıklı olduğunu belirlediğimiz Hermes ve Slaney patates çeşitlerinde, Asg1 gen ifadesi kantitatif olarak belirlenerek, bu genin patates genotiplerinin tuz tolerans yeteneklerinin saptanmasinda erken seleksiyon çalışmalarında kullanılabilirliği belirlenmiştir.

\section{Materyal ve Yöntem}

\subsection{Materyal}

\subsubsection{Bitki materyali, in vitro kültüre alınması, bitkiciklerin} üretimi ve tuz stresi

Çalışmada, Slaney ve Hermes patates çeşitleri kullanılmıştır. Çeşitlere ait yumrular dezenfekte edilerek, karanlık koşullarda 4 hafta $20-24{ }^{\circ} \mathrm{C}$ 'de filizlenmeye bırakılmıs, $1.0-1.5 \mathrm{~cm}$ uzunluğundaki sürgünler \% 75'lik etanol'de $2 \mathrm{dk}$ bekletilerek, daha sonra \% 15'lik seyreltilmiş sodyum hipoklorit çözeltisinde $20 \mathrm{dk}$ steril edilmiştir. Meristematik dokular kesilerek \% 3 sukroz içeren MS (Murashige ve Skoog 1962), minarel tuzları ve vitaminleri, \% 3 sukroz ve $\% 0.8$ agar içeren ortamda kültüre alınmıştır. Gelişen 4-5 haftalık tuza dayanıklı ve hassas olduğu düşünülen bitkiciklerde $0.5 \mathrm{~cm}$ büyüklüğündeki tek yapraklı koltuk altı meristemleri $1 \mathrm{mg} \mathrm{L}^{-1}$ BAP ve $7 \mathrm{~g} \mathrm{~L}^{-1}$ agar ve 50,100 ve $150 \mathrm{mM} \mathrm{NaCl}$ içeren ve içeremeyen MS besin ortamında gelişen bitkiciklerden 6 hafta sonra total RNA izolasyonu yapılmıştır.

\subsection{Yöntem}

\subsubsection{Gen ifade analizi}

\subsubsection{Total RNA izolasyonu}

Total RNA izolasyonu trizol metodu kullanılarak yapılmıştır. Total RNA'lar miktar ve kalite kontrolü için nanodrop spektrofotometre ve RNA için özelleştirilmiş agaroz jel ile kontrol edilmiştir. Total RNA numuneleri DNaseI enzimi (\#EN0521 Thermo Scientific) ile muamele edilerek muhtemel DNA kontaminasyonları tamamen elenmiştir. DNaz uygulamasını takiben numuneler kolon bazlı temizleme sistemi (\#K0842 Thermo Scientific) ile kit protokolleri ile saflaştırılmış ve cDNA'ya çevirmeye hazır hale getirilmiştir. cDNA sentezi için Reverseaid First Strand cDNA sentez kiti (\#K1622 Thermo Scientific) kullanılmıştır. 2000 ngRNA, $1 \mu$ l Oligo (dT) Primerleri $\mathrm{ddH}_{2} \mathrm{O}$ ile $12 \mu \mathrm{l}$ hacme tamamlandiktan sonra 5 dakika $65^{\circ} \mathrm{C}$ ' de inkübasyonun ardından buza gömülmüştür. Daha sonra $4 \mu 15 \mathrm{X}$ Reaksiyon Tamponu, $1 \mu 1$ RNaz inhibitörü, $2 \mu 1$ dNTP karışımı, $1 \mu 1$ Revers Transkriptaz eklenerek $42^{\circ} \mathrm{C}^{\prime}$ de 1 saat, $70^{\circ} \mathrm{C}$ 'de 5 dakika bekletilmiştir. Eş zamanlı PZR uygulamalarında normalizasyon işlemleri için EF1a (Elongation factor) kullanılmıştır. RT-PCR analizinde, $0.7 \mu \mathrm{M}$ Forward Primer, $0.7 \mu \mathrm{M}$ Revers Primer, $2 \mu \mathrm{g}$ cDNA, 1X SYBR Green master karşımı, $3.5 \mu 1 \mathrm{H}_{2} \mathrm{O}$ ve toplam hacim $20 \mu \mathrm{l}$ olacak şekilde reaksiyon hazırlanmıştır. SYBR Green I boyası kullanılarak gercekleştirilen kantitasyonu takiben PCR'ın etkinliğini saptamak ve herhangi bir dimer oluşumu olup olmadığını gözlemlemek amacıyla Erime Eğrisi Analizi yapılmıştır. EF1a geni $\quad$ için $\quad$ R-5' GTCGATTCTGGAAAGTCGACC-3', F-3'AATGTCAATGGTGATACCACGC-5, primerleri kullanılmıştır. Asg1 geni için Arabidopsis bitkisindeki ortolog genin NCBI veri tabanında mRNA sekansına (At5g17640) ulaşıldıktan sonra Blastin analizi yapılarak primer tasarımı yapılmıştır. Asg1 geni için F- 5'CTGGACCCTGATCCAAGATATGTT- 3' R- 3'CTGTCCTGACTAAACTTGCAACTG- 5 , primerleri kulanılmıştır. RT-PCR'da $95^{\circ} \mathrm{C}$ 'de $10 \mathrm{dk}$ ön denatürasyondan sonra, $\quad 95^{\circ} \mathrm{C}$ 'de 20 sn denatürasyon, 20 sn $60^{\circ} \mathrm{C}^{\prime} \mathrm{de}$ hibridizasyon, $72{ }^{\circ} \mathrm{C}$ 'de 20 sn elongasyon olmak üzere 40 döngü amplifikasyon RT-PCR koşulları uygulanmıştır. $65^{\circ} \mathrm{C}$ $95^{\circ} \mathrm{C}$ arasında erime eğrisi analizi yapılmıştır. $\Delta \mathrm{CT}$ verileri, Roche Light Cycler yazılımında işlenmiştir. PZR sonucunda her bir örnek için Ct (Cycle Treshold - Eşik Döngü) değerleri elde edilmiştir. Genlerin anlatım düzeyleri, 2 $2^{\text {(-Delta DeltaCt })}$ metodu kullanılarak hesaplanmıştır.

\section{Bulgular ve Tartışma}

Real-time PCR uygulaması, Roche Light Cycler cihazında gerçekleştirilmiştir. cDNA seri dilüsyonlarından Asg1 geni için hem Hermes hem de Slaney çeşidinde oluşturulan standart eğri grafiklerine ait validasyon değerleri aşağıda gösterilmiştir (Şekil 1, 2, 3, ve 4).

In vitro testlerde fizyolojik tuza toleranslı olduğu düşünülen Slaney çeşidinde ise $50 \mathrm{mM} \mathrm{NaCl}$ uygulamasında kontrole göre istatistiki anlamda önemli ölçüde (\% 96) artış gösterdiği, 100 $\mathrm{mM}$ ve $150 \mathrm{mM}$ 'lı $\mathrm{NaCl}$ konsantsyonlarında ise kontrole göre gen ifadesindeki artış $50 \mathrm{mM} \mathrm{Nacl}$ konsantrasyonuna göre azalarak kontrole göre ise artarak devam ettiği görülmüştür.

Değerler kontrole (0) göre olan kat artış ve azalışlarını ifade etmektedir. Ayrıca her çeşide ait Real-Time PCR verileri kendi kontrolüne göre normalize edilmiştir.

Hassas olduğu düşünülen Hermes çeşidinde $50 \mathrm{mM}$ tuz uygulamasında kontrole göre \% 16 oranında gen ifadesinde düşüş görüldüğü, $\quad 100 \mathrm{mM}$ ve $150 \mathrm{mM}$ 'lik tuz konsantsyonlarında ise Asg1 gen ifadesi çok düşük oranda arttığ 1 ancak kontrole göre istatistiki olarak önemli seviye olmadığı saptanmıştır (Şekil 3).

Bitkilerde tuz stresi, organ düzeyinde etkisi, hücresel düzeyde etkisi, organel düzeyinde etkisi, fotosentez üzerine etkisi, (stomaların kapanması, fotosentetik mekanizmanın bozulması) ve oksidatif stres oluşumu olarak ele alınabilir (Çulha ve Çakırlar 2011). Bitkilerde tuz ve kuraklık stresi başta olmak üzere streslere tepkisel olarak pekçok sinyal iletim yolu işlevi ile cevap verilmekte, pek çok yolakta yer alan gen ifade olmaktadır. İfadesi artan bu genlerin ürettiği moleküller görevlerine göre çevresel streslere karşı koruyucu, stres cevaplarında sinyal iletimini ve gen ifadelerini düzenleyici olarak görev alan moleküllerdir (Seki ve ark. 2003). Ayrıca, tuzluluk toleransinda, transkripsiyon faktörleri ve transkripsiyon ilişkili proteinlerin seviyelerinin önemli bir rol oynadığ 1 proteomik çalışmalarla gösterilmiştir (Zhang ve ark. 2012). Bitkiler tuz stresinde transpirasyon oranı azaltmak için stomalarını kapatmakta ve yaprak yüzeylerini daraltmaktadır (Karanlık 2001; Yaşar 2003). Stomaların kapanmasında fonksiyonel olan ABA, tuz stresinde artarak ozmotik cevap genlerini ile iyon taşıyıcılarını regüle etmektedir (Uno ve ark. 2000; Shen ve ark. 2001; Hoth 2002). Abiyotik Stres Geninin (Asg1) de patates ve Arobidopsiste işlevsel analizi sonucunda da, ABA bağımlı yolakta stres koşullarında ozmotik bir pozitif 


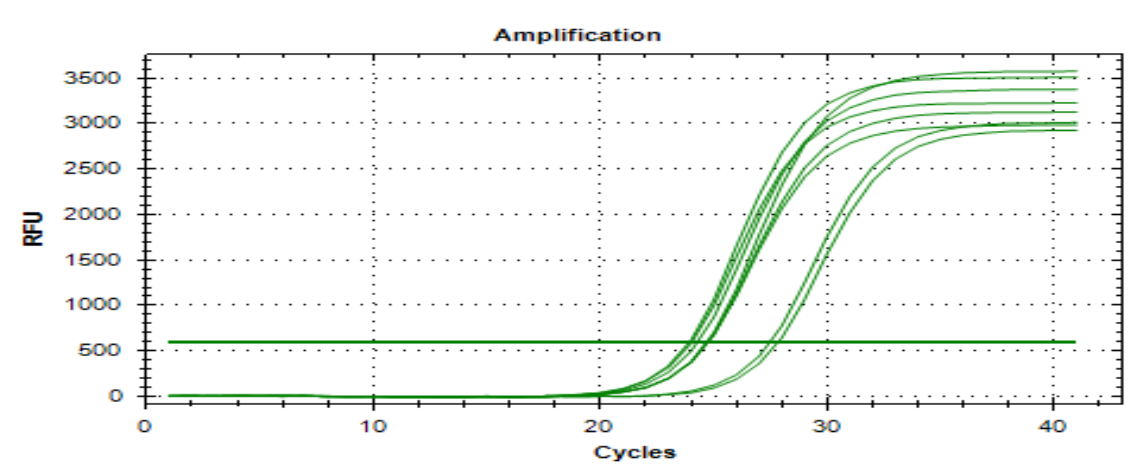

Şekil 1. Slaney çeşidinde Asg1 geni standart eğri grafiği oluşturmak üzere PCR'1 yapılan cDNA seri dilüsyonları pik görüntüsü. Figure 1. Serial dilutions of CDNA made by PCR to generate Asg1 broad standard curve graph in the Slaney variety.

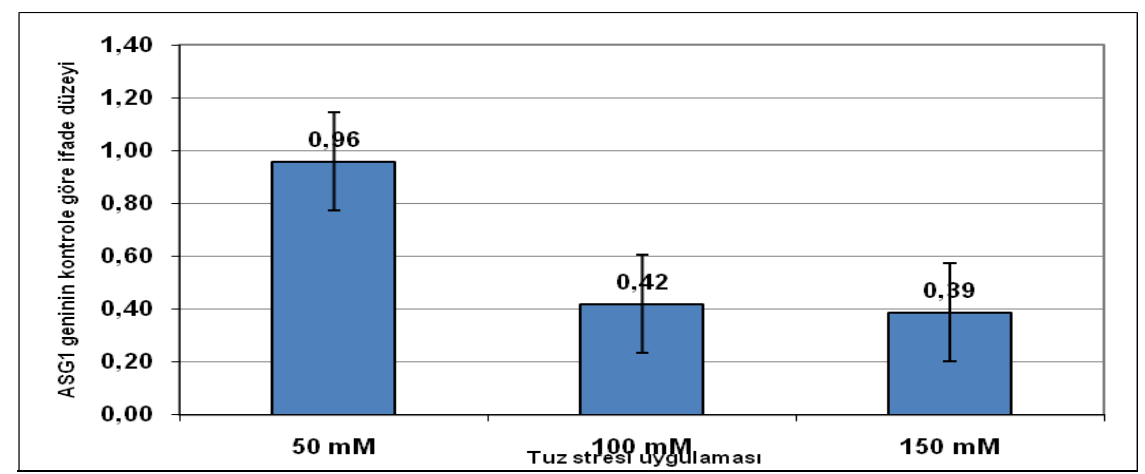

Şekil 2. Asg1 geninin farklı koşullarda tuz stresine maruz kalmış Slaney çeşidi yapraklarındaki mRNA seviyeleri. Figure 2. mRNA levels of Asg 1 gene in Slaney variety leaves exposed to salt stress.

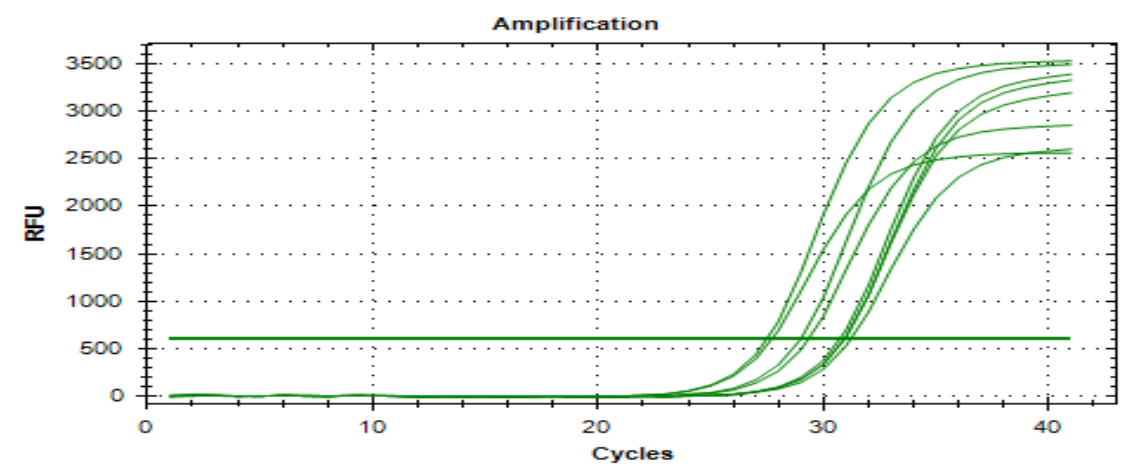

Şekil 3. Hermes çeşidinde Asg1 geni standart eğri grafiği oluşturmak üzere PCR'1 yapılan cDNA seridilüsyonları pik görüntüsü Figure 3. Serial dilutions of CDNA made by PCR to generate Asg1 broad standard curve graph in the Hermes variety.

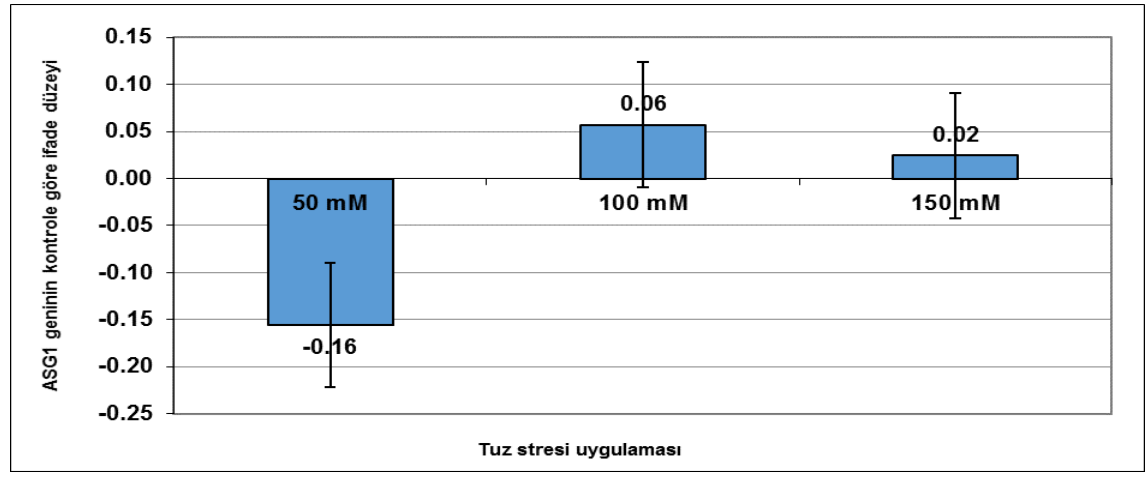

Şekil 4. Asg1 geninin farklı koşullarda tuz stresine maruz kalmış Hermes çeşidi yapraklarındaki mRNA seviyeleri.

Figure 4. mRNA levels of Hermes variety leaves exposed to salt stress under different conditions of Asg 1 gene. 
regülatör olduğu, hem patates hemde Arabidopsis'de tuz stresi ile indüklendiği görülmüştür (Batelli ve ark. 2012). Stres koşullarında çimlenmede olduğu gibi, dehidrasyondan sonra stoma kapanması büyük oranda $\mathrm{ABA}$ tarafindan kontrol edilir (Xiong ve Zhu 2003; Ruggiero ve ark. 2004; Raghavendra ve ark. 2010). Bu bağlamda, Asg1 geni ifadesi, strese duyarlı genlerin büyük setlerini düzenleyen büyük bir sekonder mesajc1 olan ABA'ya bağlı bir yol aracılığıyla regüle edilebildiği bildirilmiştir (Yamaguchi-Shinozaki ve Shinozaki 2006; Batelli ve ark. 2012). Arabidobsiste Asg1 geninin aşırı ifade ettirilmesi ile tuz stresi adaptasyonu sürecinde bitkinin gözlemlenebilen stres tepkilerini artırdığ 1 görülmüştür (Nakashima ve ark. 2009; Zou ve ark. 2011). Asg1 geni aşırı ifade ettirilen patates bitkilerinde ise $\mathrm{NaCl}$ stresine karşı hiperstoma duyarlılığ göstermekte olup, ancak stres koşullarında yumru verimini önemli ölçüde artırmadığı saptamıştır (Batelli ve ark. 2012). Misır köklerinde tuz stresine cevap veren genler bakımından 39 farklı gen ifadesinin kinetik profili belirlenmiş, analiz edilen 472 adet tuz stres ile ilişkili genlerden sadece 5 tanesinin, patates Asg1 genine benzer bir model gösterdiği saptanmıştır (Wang ve ark. 2003). Bu çalışmada da Asg1 geninin, in vitro testlerde toleranslı olduğunu belirlediğimiz Slaney çeşidinde sürekli olarak kontrol seviyesinin üzerinde ifade olduğu gözlenmiştir. $100 \mathrm{mM}$ ve $150 \mathrm{mM}$ 'lı $\mathrm{NaCl}$ konsantrasyonlarında ise kontrole göre gen ifadesindeki artış 50 $\mathrm{mM} \mathrm{NaCl}$ konsantrasyonuna göre azalarak kontrole göre ise artarak devam ettiği görülmüştür. Hermes çeşidinde ise $50 \mathrm{mM}$ tuz uygulamasında kontrole göre \% 16 oranında gen ifadesinde düşüş görüldügüu, çeşitlerin gen ifadelerinin mukayese edilmesi durumunda ise Slaney çeşidinde Asg1 geni ifadesinin tüm tuz konsantrasyonlarında Hermes çeşidinden daha fazla olduğu saptanmıştır. Literatürde bu patates çeşitleriyle tuz stresine yönelik gen ifadesi çalışmasına rastlanmamış, elde edilen veriler in vitro testlerle uyumludur.

\section{Sonuç}

Bu çalışma ile Asg1 geninin tuz stresine karşı savunmada literatürlerle uyumlu olarak rol oynayabileceğini teyit edilmiştir. Ayrıca bu genin patates çeşitlerinin tuz tolerans yeteneklerinin saptanmasında erken seleksiyon çalışmaları açısından kullanılabileceği düşünülmektedir.

\section{Kaynaklar}

Batelli G, Massarelli I, Van Oosten M, Nurcato R, Vannini C, Raimondi G, Leone A, Zhu JK, Maggio A, Grillo S (2012) Asg1 is a stressinducible gene which increases stomatal resistance in salt stressed potato. J Plant Physiol 169 (18): 1849-57.

Çulha Ş, Çakırlar H (2011) Tuzluluğun bitkiler üzerine etkileri ve tuz tolerans mekanizmaları. AKÜ FEBİD 11: 11-34.

Hoth S, Morgante M, Sanchez JP, Hanafey MK, Tingey SV, Chua NH (2002) Genome-wide gene expressionprofiling in Arabidopsis thaliana reveals new targets of abscisic acid and largely impaired gene regulation in the abi1-1 mutant. Journal of Cell Science, 115(24): 4891-4900.

Karanlık S (2001) Değișik buğday genotiplerin de tuz stresine dayanıklılık ve dayanıklılığın fizyolojik nedenlerinin araștırılması . Doktora Tezi, Çukurova Üniversitesi Fen Bilimleri Enstitüsü, Adana.

Kreps JA, Wu Y, Chang HS, Zhu T, Wang X, Harper JF (2002) Transcriptome changes for Arabidopsis in response to salt, osmotic, and cold stress. PlantPhysiology, 130(4): 2129-2141.

Maas EV (1984) Crop tolerance. California Agric 38(10): 20-21.
Munns R, Tester M (2008) Mechanisms of salinity tolerance, Annual Review of Plant Biology 59: 651-681.

Murashige T, Skoog F (1962) A revised medium for rapid growth and bio assays with tobacco tissue cultures, Physiol. Plant., 15: 473497.

Nakashima K, Ito Y, Yamaguchi-Shinozaki K (2009) Transcriptional regulatory networks in response to abiotic stresses in arabidopsis and grasses. Plant Physiol 149: 88-95.

Raghavendra AS, Gonugunta VK, Christmann A, Grill E (2010) ABA perception and signalling. Trends Plant Sci 15: 395-401.

Ruggiero B, Koiwa H, Manabe Y, Quist TM, Inan G, Saccardo F (2004) Uncoupling the effects of abscisic acid on plant growth and water relations. Analysis of sto1/nced3, an abscisic acid-deficient but salt stress-tolerant mutant in arabidopsis. Plant Physiol 136: 31343147.

Sahi C, Singh A, Blumwald E, Grover A (2006) Beyond osmolytes and transporters: novel plant salt-stress tolerance-related genes from transcriptional profiling data. Physiologia Plantarum, 127(1): 1-9.

Seki M, Kamei A, Yamaguchi-Shinozaki K, Shinozaki K (2003) Molecular Responses to drought, salinity and frost: common and different paths for plant protection. Current Opinion in Biotechnology 14: 194-199.

Shen Q, Chen CN, Brands A, Pan SM, Tuan-Hua DH (2001) The stressand abscisic acid-induced barley gene HVA22: developmental regulation and homologues in diverse organisms. Plant Molecular Biology 45(3): 327-340.

Shimazaki T, Endo T, Kasuga M, Yamaguchi-Shinozaki K, Watanabe KN, Kikuchi A (2016) Evaluation of the yield of abiotic-stresstolerant AtDREB1A transgenic potato under saline conditions in advance of field trials. Breeding Sci 66: 703-710.

Tuteja N (2007) Mechanisms of high salinitytolerance in plants. Methods in Enzymology 428: 419-438.

Uno Y, Furihata T, Abe H, Yoshida R, Shinozaki K, YamaguchiShinozaki K (2000) Arabidopsis basicleucinezipper transcription factors in volved in an abscisicacid-dependent signal transduction pathway under droughtandhigh-salinityconditions. Proceedings of the National Academy of Sciences of the United States of America, 97(21): 11632-11637.

Wang H, Miyazaki S, Kawai K, Deyholos M, Galbraith DW, Bohnert HJ (2003) Temporal progression of gene expression responses to salt shock in maize roots. Plant Mol Biol 52: 873-891.

Xiong L, Zhu JK (2003) Regulation of abscisic acid biosynthesis. Plant Physiol 133: 29-36.

Yamaguchi-Shinozaki K, Shinozaki K (2006) Transcriptional regulatory networks in cellular responses and tolerance to dehydration and cold stresses. Annu Rev Plant Biol.; 57: 781-803.

Yaşar F (2003) Tuz stresi altındaki patlıcan genotiplerinde bazı antioksidant enzim aktivitelerinin in vitro ve in vivo olarak incelenmesi. Doktora Tezi, Yüzüncü Y1l Üniversitesi Fen Bilimleri, Van.

Zhang H, Han B, Wang T, Chen S (2012) Mechanisms of plant salt response: insights from proteomics. Journal of Proteome Research 11: 49-67.

Zhu JK (2002) Salt and drought stress signal transduction in plants. Annual Review of Plant Biology 53: 247-73.

Zou C, Sun K, Mackaluso JD, Seddon AE, Jin R, Thomashow MF (2011) Cis-regulatory code of stress-responsive transcription in Arabidopsis thaliana. Proc Natl Acad Sci USA 108: 14992-14997. 